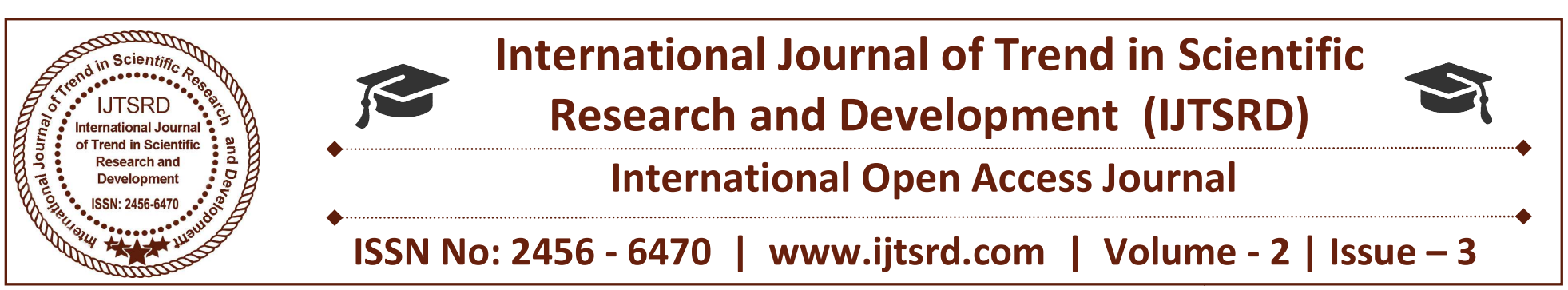

\title{
The Impact of Marketing Mix Variables on Consumer Behavior in the Brewery Industry- A Study
}

\author{
Etumbih Elvis Akweli \\ Gyan Vihar International School of Business \\ Management, Suresh Gyan Vihar University, \\ Jaipur, Rajasthan, India
}

\author{
Dr Swati Pandy Mishra \\ Assistant Professor, ISBM Department, \\ Suresh Gyan Vihar University, Jaipur, \\ Rajasthan, India
}

\section{ABSTRACT}

According to "holistic" marketing era or call it consumer era which is today known as Modern marketing, everything in marketing matters. Marketing in this era is integrated with all aspects of a company's operations in terms of pricing, production, place of distribution, advertising or promotion so that the company can respond quickly and effectively to changes or opportunities in the marketplace. In this regard, marketing mix variables should not be underestimated as it may have internal as "well as external consequences considering its prominence on consumer behavior which is a symbolic environment in business. Thus, the objective of this research is to study the impact of marketing mix variables on consumer behavior in modern business. Considering the changing nature of consumer behavior regarding their buying decision process, this piece of work will help individual businessmen, organizations or companies and the entire public to establish a tradeoff that exists between the marketing mix elements of the company and consumer behavior in this case satisfaction. The proposed hypothesis in this study stated that marketing mix will have a significant impact on consumer behavior. The sample area of study used was Ombe town which is situated along the Mutengene-Limbe highway of an attitude of about $400-600 \mathrm{~m}$ above sea level. It is a small but fast growing town in terms of human population, industrial and road network. Random sampling was done with the help of questionnaires as a primary source of data to collect the data used in testing the hypothesis and it was structured to capture the objectives of the research while both the descriptive and inferential statistical method of data analysis was used to analyze the data collected. The analysis done in the research proved that marketing mix variables have an impact on consumer behavior. The study will enable individual businessmen and companies to integrate marketing mix variables and consumers behavior in making strategic decisions in their organization.

Keywords: 'Marketing Mix, Consumers' behavior, Brewery Industry and Customer's Satisfaction

\section{INTRODUCTION}

Consumer behavior is an important aspect to study in business. First thing first a consumer is the end user of a firm's product. So, consumer behavior could be defined as those acts of individuals that are directly involved in obtaining and using economic goods and services, including the decision processes that precede and determine those acts. Therefore, understanding the consumer is a necessity for marketers in this era of competition where consumer needs and preferences are continuously changing. Given the changes in factors like demographics, psychographic and lifestyles, their behavioral changes could become great business opportunities for alert marketers and at the same time a threats for marketers who fail to adapt. Since consumers acquire, use, and dispose of products and services created by organizations, they go through several cognitive and behavioral processes while making their purchase and consumption decisions.

Marketing involves a range of processes concerned with identifying the needs and wants of potential 
consumers, and providing a long lasting solution that can satisfy those needs. By identifying the needs and wants of consumers, four key elements are involved which include the product, price, place and promotion which are referred to in marketing as the 4Ps. Marketing thus is seen to anticipate and identify consumer needs and demand and to develop method of satisfying them while at the same time making profit or other key objectives of the organization. Since the purpose of a business is to create and keep a customer, marketing managers or directors of business organizations should try to focus on consumers' demands because customers are considered as Kings in modern marketing (consumer's era). To also understand marketing mix briefly, scholars have define it as an integration of product, place, price, promotion (4Ps) for the tactical management of customers relationship in business. Marketing mix thus is a term commonly used by marketers to describe how the (4Ps) could be manipulated by organizations or businessmen to enable their businesses to be profitable and or to achieve other objectives. Process, People, and Physical evidence are other three elements in the service sector, as will be seen also in the course of this study, which greatly affect consumer behavior. Marketers therefore find it crucial, not only on how to cater for the existing needs of their consumers but also on how to prepare for their future needs because they lack knowledge on how consumers make their decision on which brand instead of another and what factors influence their decision. Knowledge about consumers in making decisions also, is essential to marketers in taking various business decisions relating to product development, packaging, pricing, distribution, promotion, communication, and many other variables which actually influence the behavior of consumers.

Thus the help of consumer behavior, guide business organizations in understanding internal variables like perception, learning, motivation, attitude and personality as well as external variables like family, culture, reference groups and social class alongside their influences on consumer decision making process. Motivation is what stimulates all human behavior. The process of motivation is initiated by the tension in which unsatisfied wants creates. Marketers therefore, should deem it necessary to know the motives influencing the consumer as they initiate and direct all human behavior (including consumer behavior). Personality of a person is the result of his/her individual traits which distinguishes one person from another and it also determines how and why a consumer behaves in a particular way. By personality through what is known as self-concept, products that have images that are similar to the views of a person, will easily be chosen by him/her since every consumer knows his/her opinion and also because most individuals often imagine and associate certain attributes with regard to their tastes and personalities. Buying a product or a brand and how frequent consumers visit stores is influenced by the images they have in their minds. As consumers are inclined toward products that match their selves, marketers need to be familiar with the self-concept which helps them to understand, predict, and direct the purchase decisions of consumers. It should be noted that most consumers would always want to get goods and services which are of best quality at the cheapest possible price and in a most accessible place. Consumer behavior therefore, greatly depends on the marketing mix variables even though other variables equally have an impact on consumer behavior. This research shall strictly be limited only on the impact of marketing mix variables on consumer behavior. We are ascertained sometimes that we know where the world should go but unless we are in touch with our customers, our model of the world can diverge from reality. There is no substitute for innovation, of course, but innovation is no substitutes for being in touch either, Steve Ballmer, CEO, Microsoft Corporation.

Mindful of the fact that consumer behavior is unpredictable, the marketing department of business organizations would be required to embark in a serious market research exercise. There are two types of market research that exist which are the quantitative research that involve collecting of information by using techniques such as questionnaires and other forms of survey and the Qualitative research which involves working with smaller samples of consumers, often asking them to discuss products and services while researchers take notes about what they have to say. Most marketing departments usually combine both forms of research to ensure that their companies have good marketing focus in everything that they do. Marketing departments in organizations work very closely with production departments to make sure that new and existing products are tied closely with the needs and expectations of potential customers. Most focused organizations in modern market will seek to find out 
what their customers want because consumers have different ways they think, believe, perceive and personalize among other characteristics that are affected by the marketing mix elements which intend have an influence on their success. It is therefore in this light that business organization must understand that consumers buy satisfaction and not just the product as per say and from a marketing viewpoint, consumers' satisfaction depends on the ability of a products' quality and benefits to meet his/her needs.

\section{OBJECTIVES OF THE STUDY:}

Main Objective is to examine the impact of marketing mix variables on consumer's behavior.

Sub Objectives Include:

- To examine whether the pricing policy of Brasseries du Cameroun affects consumer behavior.

- To examine whether the product quality of this company affect consumer behavior.

- To understand if promotion strategy of this company have an impact on consumer behavior.

- To examine if the place of distribution can affect consumer behavior.

\section{The Hypotheses of the Study:}

The relationship between the marketing mix variables and consumer behavior of this study will be predicted and explained using the following hypothesis;

Ho: Marketing mix variables has no significant impact on consumer's behavior

H1: Marketing mix variables has a significant impact on consumer's behavior

Where,

Ho is the null hypothesis.

$\mathrm{H} 1$ is the alternative hypothesis.

\section{Limitations of the study:}

This study is limited to one region and in one deport in Cameroon, namely the South West region around the Ombe area which is the most recently created deport by Brasseries du Cameroun and thus the impact of its existence has not yet been really felt by the public. It did not take into account deports in different region of the country. Hence this may place some constraints in drawing inferential conclusions. Therefore, it would be useful in further studies to consider other variables to determine consumers' behaviour in the brewery industry. Again, there was limited time and funds for effective study on the selected area.

\section{Review of Literature}

According to Philip (2006)1 a consumer's buying behavior is influenced by cultural, social, and personal factors. Consumer buying behavior refers to the buying behavior of end users or final consumers. In his study, he used the buyer behavior model which he developed to illustrate how consumers respond to various marketing efforts. According to Neil Borden (2012)2, marketing mix is a term used to describe some controllable factors (product, price, place, and promotion) over which an organization or business has some specific control to enable it satisfy its market profitably or achieve its objectives. This marketing mix is made up of four main controllable elements popularly known as the "4Ps". These popular "4Ps" are the efforts of Jerome McCarthy and Philip Kotler3. Typically a firm can change any of these marketing mix elements to achieve the desired response from the potential buyers. Philip Kotler (2000)4 indicated that the 4Ps represents the sellers' view of the marketing tools available for influencing buyers. From the buyers' point of view, each marketing tool is designed to deliver a customer benefit. Lauter (1990)5 suggested that the seller's 4Ps correspond to the customer's 4Cs which include; customer solution, cost, convenience, and communication which he explained that product represent customer solution, price denotes customer cost, place stands for convenience and promotion stand for communication. According to Lyonga (2007)6, a product is referred to as the need-satisfying offer of an organization or business. A product is not limited to goods only as many may believe; products also include ideas and services. Therefore, a product is anything that can provide costumer's satisfaction. Since costumers buy satisfaction and not just the physical product, business should then focus on what will satisfy the consumers most because it is the consumer who has the final say as to whether a product is satisfactory or not which ties with the marketing phrase that says "Customer is the King". According to Kotler (2006)7, promotion means activities that communicate the merits of the product 


\section{DATA PRESENTATION:}

Table 1 - Number of Respondents on Categories and the Percentage

\begin{tabular}{|l|l|l|l|}
\hline Categories & Classification & Number of Respondent & Percentage \% \\
\hline Age & $18-25$ years & 17 & 68 \\
& 26-35years & 05 & 20 \\
& $36-49$ years & 03 & 12 \\
& 50 and above year & 0 & 0 \\
& & 25 & 100 \\
\hline Sex & Male & 15 & 60 \\
& Female & 10 & 40 \\
& & 25 & 100 \\
\hline Product customers & Consumers & 22 & 80 \\
& Distributors & 01 & 04 \\
& Both & 04 & 16 \\
& & 25 & 100 \\
\hline
\end{tabular}

And persuade target customers to buy it. Today's consumer faces richer information environments than ever before and this impact their buying behavior. Price also may thus be a very important initial signal of what quality of a product a consumer is to expect (Randall 2001)8. In this research, price decision includes least price, discounts, payment periods, and terms of payment. All this price decision made by the brewery producer will influence the purchasing behavior of the clients. Randall (2001)9 in explaining the economic reason for the existence of intermediaries is that it is more efficient. Neil Borden (Borden, N. 1964) 10 who first started using the phrase marketing mix in 1949 said when blending the mix elements (4P), marketers must consider their target market. They must understand the wants and needs of the market customer then use these mix elements in constructing and formulating appropriate marketing strategies and plans that will satisfy these wants.

\section{Research Methodology:}

The data was collected from a sample size of 25 randomly selected Brasseries consumers of both sex using self-administered questionnaires. Based on this the analysis was carried out and the descriptive and the inferential statistical methods were used. The descriptive statistics enabled the researcher to describe the data collected and come out with the measures of central tendency such as the mean and the standard deviation of the population. The inferential statistics enabled the researcher to make conclusions and generalization about the population based on information contained in the sample. A 5\% level of significance was used to test the data. This $5 \%$ of significance is appropriate for the study in that it reduces the probability of type I and or type II errors. The inferential statistical test chosen was the ztest based on the normal-distribution. This will be used in making inferences about population mean when testing the hypothesis for the main objective. Scale with validity and reliability. The sub objectives will be analysed with the use of a descriptive tool which is the percentage.

\section{Product Customers of Brasseries du Cameroun:} Majority of the respondents $80(\%)$ of them are consumers, $16(\%)$ of them are distributors whereas only $04(\%)$ are both consumers who are enrolled in distribution. These imply that most of the respondents have a good knowledge of Brasseries products and their corresponding prices since they are consumers. Also, for those who are involved in both consumption and distribution, they provide better information since they know both the wholesale and retail prices of Brasseries products.

Sex: out of the 25 consumers, $60 \%$ are male while $40 \%$ are female.

Age: Sample of respondent are classified into four categories out of which $68 \%$ belong to the age group of 18-25years, $20 \%$ fall under 26-35years age group meanwhile $12 \%$ came from 36-49 age group and $0 \%$ were above 50years. 
Table 2 -Number and Percentage of Consumers based on Marketing Mix and the Buying behavior

\begin{tabular}{|l|l|l|l|l|}
\hline OPTION & Price & Promotion & $\begin{array}{l}\text { Product } \\
\text { Quality }\end{array}$ & Place \\
\hline Number & 10 & 4 & 6 & 5 \\
\hline Percentage (\%) & 50 & 16 & 24 & 20 \\
\hline
\end{tabular}

\section{Source: Field work by Etumbih Elvis, 2018}

Going by the main objective of the study, responses shows that half of the respondents consider the price of a product first before purchasing the product. To them, price is the most important marketing mix variable that determines their consumption. Product quality ranks the second (24\%) marketing mix variable most preferred by consumers when going in for consumption of the product, while the place element is rank third, as $20 \%$ of the respondents feel that place is one of the most influential marketing mix variable and lastly $16 \%$ of the 25 respondents noted that promotion can also be looked upon as one of the most influential marketing mix element. It is therefore based on the above data that promotion is ranked as the last most influential marketing mix variable in this research work.

\section{Table 3: Frequency Table}

\begin{tabular}{|c|c|c|c|c|c|c|c|c|c|c|c|c|c|c|c|c|c|c|c|c|c|c|c|c|c|c|}
\hline $\begin{array}{l}\text { Number of } \\
\text { Respondents/Details on } \\
\text { Marketing Mix variables }\end{array}$ & 1 & 2 & 3 & 4 & 5 & 6 & 7 & 8 & 9 & 10 & 11 & 12 & 13 & 14 & 15 & 16 & 17 & 18 & 19 & 20 & 21 & 22 & 23 & 24 & 25 & $\begin{array}{l}\text { frequ } \\
\text { ency }\end{array}$ \\
\hline $\begin{array}{l}\text { A. place of distribution and } \\
\text { buying behavior }\end{array}$ & 1 & 1 & 0 & 1 & 0 & 1 & 0 & 1 & 0 & 1 & 1 & 0 & 1 & 1 & 1 & 0 & 1 & 1 & 1 & 1 & 0 & 1 & 1 & 1 & 0 & 17 \\
\hline $\begin{array}{l}\text { B. Proximity to Brasseries } \\
\text { products }\end{array}$ & 0 & 0 & 1 & 0 & 1 & 1 & 0 & 0 & 1 & 0 & 1 & 0 & 0 & 0 & 0 & 1 & 0 & 1 & 1 & 1 & 1 & 1 & 0 & 0 & 0 & 11 \\
\hline $\begin{array}{l}\text { C. Price and influence on } \\
\text { consumption }\end{array}$ & 1 & 1 & 1 & 1 & 1 & 1 & 1 & 0 & 1 & 1 & 1 & 0 & 1 & 0 & 1 & 1 & 1 & 1 & 1 & 1 & 1 & 1 & 1 & 1 & 1 & 23 \\
\hline $\begin{array}{l}\text { D. Satisfaction with } \\
\text { Brasseries prices }\end{array}$ & 1 & 1 & 1 & 1 & 1 & 1 & 1 & 1 & 1 & 1 & 1 & 1 & 1 & 0 & 1 & 0 & 0 & 0 & 1 & 1 & 1 & 1 & 1 & 1 & 0 & 20 \\
\hline $\begin{array}{l}\text { E. Promotion and buying } \\
\text { behavior }\end{array}$ & 1 & 1 & 1 & 1 & 1 & 1 & 1 & 1 & 1 & 1 & 1 & 0 & 1 & 1 & 0 & 1 & 1 & 1 & 1 & 1 & 0 & 0 & 1 & 1 & 1 & 21 \\
\hline $\begin{array}{l}\text { F. Awareness of Brasseries } \\
\text { Products }\end{array}$ & 0 & 1 & 1 & 1 & 0 & 1 & 1 & 1 & 1 & 0 & 0 & 1 & 1 & 1 & 1 & 1 & 1 & 1 & 1 & 1 & 0 & 1 & 1 & 1 & 1 & 20 \\
\hline $\begin{array}{l}\text { G. Product equality and } \\
\text { buying attitude }\end{array}$ & 1 & 1 & 1 & 1 & 1 & 0 & 1 & 1 & 1 & 1 & 1 & 1 & 1 & 1 & 0 & 1 & 1 & 1 & 1 & 1 & 1 & 1 & 1 & 1 & 1 & 23 \\
\hline $\begin{array}{l}\text { H. Preference to Brasseries } \\
\text { products over others }\end{array}$ & 0 & 1 & 1 & 0 & 1 & 0 & 1 & 0 & 1 & 0 & 0 & 1 & 0 & 0 & 1 & 1 & 0 & 1 & 1 & 1 & 1 & 1 & 1 & 0 & 0 & 14 \\
\hline & $5 / 8$ & $\begin{array}{l}7 / \\
8\end{array}$ & $\begin{array}{l}7 / \\
8\end{array}$ & $\begin{array}{l}6 / \\
8\end{array}$ & $\begin{array}{l}6 / \\
8\end{array}$ & $\begin{array}{l}6 / \\
8\end{array}$ & $\begin{array}{l}6 / \\
8\end{array}$ & $\begin{array}{l}5 / \\
8\end{array}$ & $\begin{array}{l}7 / \\
8\end{array}$ & $\begin{array}{l}5 / \\
8\end{array}$ & $\begin{array}{l}6 / \\
8\end{array}$ & $\begin{array}{l}4 / \\
8\end{array}$ & $\begin{array}{l}6 / \\
8\end{array}$ & $\begin{array}{l}4 \\
8\end{array}$ & $5 / 8$ & $6 / 8$ & $5 / 8$ & $\begin{array}{l}7 / \\
8\end{array}$ & $8 / 8$ & $8 / 8$ & $4 / 8$ & $7 / 8$ & $\begin{array}{l}7 / \\
8\end{array}$ & $\begin{array}{l}6 / \\
8\end{array}$ & $\begin{array}{l}5 / \\
8\end{array}$ & \\
\hline
\end{tabular}

\section{Test of Hypotheses}

Test of Null hypothesis using Chi-square $\left(\mathbf{X}^{\mathbf{2}}\right)$

That is, Ho: Marketing mix variables has no significant effect on consumer behavior.

$\mathrm{X}^{2}=\sum \frac{(O-E) 2}{E}$

Where $\quad \mathrm{X}^{2}=$ Chi- square

$\mathrm{O}=$ Observed frequency

$\mathrm{E}=$ Expected frequency 
Table 4: Calculation of Chi Square $\left(\mathrm{X}^{2}\right)$

\begin{tabular}{|c|c|c|c|c|}
\hline $\begin{array}{l}\text { Observed } \\
\text { (O) }\end{array}$ & $\begin{array}{l}\text { Expected } \\
\text { (E) }\end{array}$ & O-E & $(0-E)^{2}$ & $\frac{(0-E)^{2}}{E}$ \\
\hline 5 & 8 & -3 & 9 & 1.14 \\
\hline 7 & 8 & -1 & 1 & 0.14 \\
\hline 7 & 8 & -1 & 1 & 0.14 \\
\hline 6 & 8 & -2 & 4 & 0.5 \\
\hline 6 & 8 & -2 & 4 & 0.5 \\
\hline 6 & 8 & -2 & 4 & 0.5 \\
\hline 6 & 8 & -2 & 4 & 0.5 \\
\hline 5 & 8 & -3 & 9 & 1.14 \\
\hline 7 & 8 & -2 & 4 & 0.5 \\
\hline 5 & 8 & -3 & 9 & 1.14 \\
\hline 6 & 8 & -2 & 4 & 0.5 \\
\hline 4 & 8 & & & 3.13 \\
\hline 6 & 8 & -2 & 4 & 0.5 \\
\hline 4 & 8 & -5 & 25 & 3.13 \\
\hline 5 & 8 & -3 & & 1.14 \\
\hline 6 & 8 & -2 & 4 & 0.5 \\
\hline 5 & & -3 & 9 & 1.14 \\
\hline 7 & 8 & -1 & & 0.14 \\
\hline 8 & 8 & & & 0 \\
\hline 8 & 8 & 0 & 0 & 0 \\
\hline 4 & 8 & -4 & 16 & \\
\hline 7 & 8 & -1 d & 1htifi & 0.14 \\
\hline 7 & 8 & -1 & 1 & 0.14 \\
\hline 6 & 8 & $-2 \mathrm{e}$ & 4 & 0.5 \\
\hline 5 & 8 & -3 & 9 & 1.14 \\
\hline & (1) & \multicolumn{2}{|c|}{ UEV } & 20.3 \\
\hline
\end{tabular}

\section{Source; Field work by Etumbih Elvis, 2018}

From the Chi square statistical table,

$X^{2}=20.3$

Degree of freedom $(\mathrm{df})=\mathrm{n}-1$

Number of respondents $(\mathrm{n})=25$

Degree of freedom $(\mathrm{df})=25-1=24$

Table 4: Extract from the Chi Square Statistics Table

\begin{tabular}{|l|l|l|}
\hline \multirow{2}{*}{ Degree of freedom } & \multicolumn{2}{|l|}{ Level of Significance } \\
\cline { 2 - 3 } & $5 \%$ & $1 \%$ \\
\hline 24 & 36.415 & 42.980 \\
\hline
\end{tabular}

Source: Chi square statistical table. 


\section{Chi Square graph}

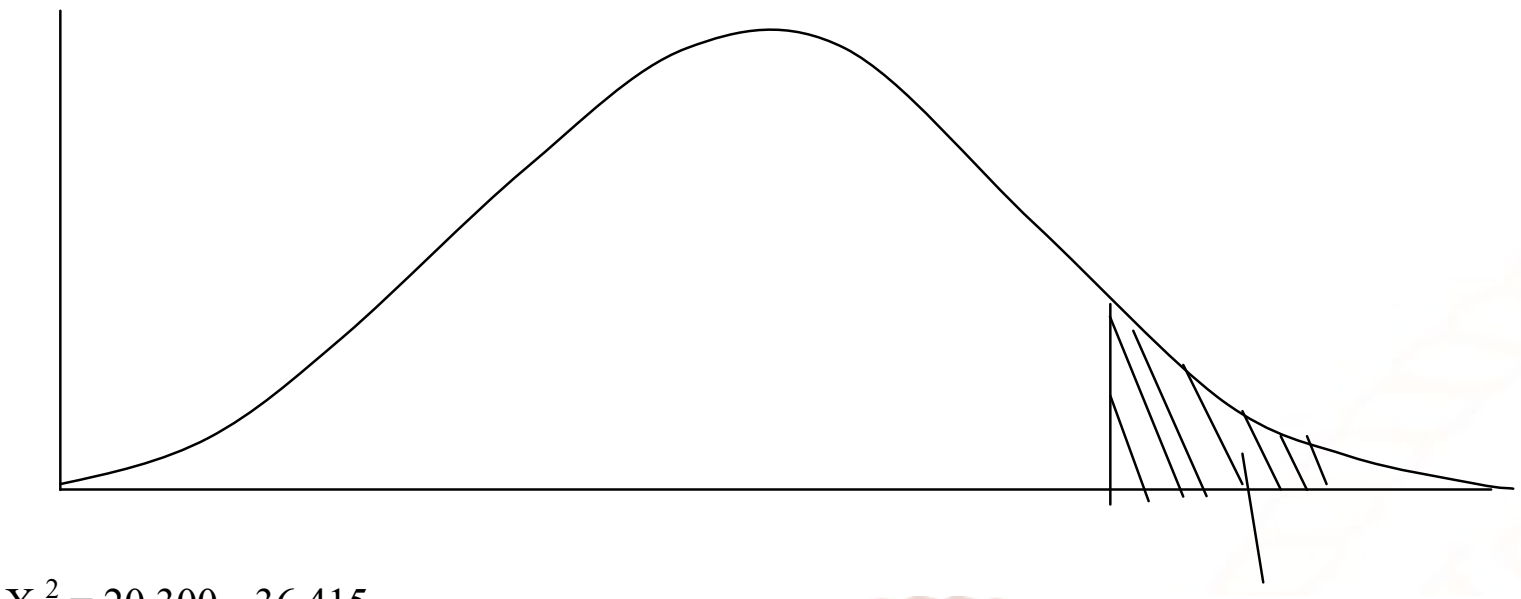

$X^{2}=20.300 \quad 36.415$

\section{Source: Field work by Etumbih Elvis, 2018}

Findings and discussion: Since the calculated value $\left(X^{2}=20.300\right)$ falls below the table critical value 36.415 , we reject the Null hypothesis which says that Marketing Mix variables have no significant impact on consumers' behaviors at 5\% level of significance. Thus, the alternative hypothesis is accepted which says that Marketing Mix variables significantly have an impact on consumers' behaviors for Brasseries products.

Other Findings included the following:

i. Price of Brasseries products affect consumption behavior because high prices will force consumers to switch to the consumption of the less expensive products by Brasseries competitors like Guinness, Kadji and other foreign/local drinks.

ii. Consumers' satisfaction depends on the price, quality of products and availability of the products. High product quality has a high influence on their buying attitude irrespective of the prices. The researcher also discovered that promotion and advertisement are central to the buying attitude of a customer as $84 \%$ confirm that in addition to product quality, they are also influenced by the promotion of the product.

iii. The respondents are interested in the place of distribution for Brasseries products before buying them. Most respondents affirm that Brasseries has made its products available to all parts of the country but when they want to buy a Brasseries drink and cannot have access to it, they can easily switch to buy that of Guinness S.A and other competitive companies but if the quality is high and the price good, most consumers become loyal to the company.

\section{CONCLUSIONS}

Nowadays where competing products are becoming more substitutable, as product quality increases and brands become more consistent, the marketing mix variables is the key success factor of any company especially Brasseries du Cameroon. Generally speaking, product quality is high, place of distribution is also accessible/available and customers are increasingly price-sensitive while the promotion benefits enjoyed by customers is increasing. From these general observations, the research findings revealed that, the marketing mix variables have a significant impact on consumer behavior thereby validating the alternative hypothesis (H1) and rejecting the null hypothesis (Ho) which states that "Marketing Mix variables have no significant impact on consumers' behavior.

\section{REFERENCES:}

1. Kotler, (2006), Marketing management, 12th ed, New Delhi, Prentice Hall

2. Nicholas, (2004) Product and Pricing Courses are underrepresented in Undergraduate Marketing Curricula. Journal of Product \& Brand Management, 4(1), 18-25

3. Mitav and Chris (2004), "The Influence of Print Advertisement Organization on Affect toward a Brand Name," Journal of Consumer Research, 17 (June), 53-65. 
4. Randall, (2001)

5. Mona and Robert, (1980),Journal of consumer research, vol 6 issue 4 page (389-405)

6. Young, (2006), "Partially Observable Markov Decision Processes for Dialog management

7. Krishna, (1994) Principles of Marketing (3rd ed.). New Jersey: Prentice Hall.

8. Randall, (2001) Marketing Management: Analysis, Planning and Control (5th ed.). New Jersey: Prentice-Hall.

9. Kotler, (2005) , Marketing and Management, Pearson Prentice Hall, Upper Saddle River, NJ, USA

10. Philip, (2006), Marketing and Management, Pearson Prentice Hall, Upper Saddle River, NJ, USA 